\title{
Mapping incidents of infant mortality arising from gastroenteritis: a case study from South-East Nigeria
}

\author{
Chukwuemeka A. Onyekwelu ${ }^{1}$, Ernest A. Obienusi ${ }^{2}$, Arinze T. Mozie ${ }^{1}$, R.U. Ayadiuno ${ }^{1}$, \\ ljeoma G. Nwosu', Yemi Adewoyin ${ }^{1}$, C.C. Ndichie ${ }^{1}$ \& Emeka E. Igboeli ${ }^{1}$ \\ ${ }^{1}$ Department of Geography, University of Nigeria, Nsukka, Nigeria \\ ${ }^{2}$ Department of Geography, Nnamdi Azikiwe University, Awka, Nigeria
}

Email:yemiadewoyin@yahoo.com

\begin{abstract}
Background: The upsurge of deaths from gastroenteritis in South-East Nigeria within the last decade has become an issue of concern. Using Anambra State as a case study, this paper examined the trend of reported cases of gastroenteritis and associated fatalities among children with a view to mapping the spatial pattern and underlying causes.

Data source and methods: Water samples collected from the available domestic sources in each of the selected 2I study localities were analyzed for aerobic heterotrophic count, total coliform, faecal coliform and enterococci, and regressed with gastroenteritis data sourced from the State epidemiological surveillance unit.

Results: The results showed that the near-epidemic 58,269 incidents of gastroenteritis recorded in Anambra State, Southeast Nigeria between 2004 and 2008 had a spatial pattern and occurred in clusters with the highest number of 287 deaths occurring in Idemili North/South constituency. The study further showed that the consumption of contaminated water was responsible for the spread of the disease

Conclusion: Hand washing practices, food hygiene, proper waste management, and the provision of basic infrastructure for improved health outcomes among the population are suggested inorder to curb the spread of gastroenteritis.
\end{abstract}

Keywords: Enteritis Viruses, Epidemiology, Gastroenteritis, Heterotroph, Sustainable Development Goals.

\section{Introduction}

Nigeria is the seventh largest country in the world and has one of the highest population growth rates. By the year 2050, Nigeria would rank the fourth most populous country in the world with a population in excess of 300 million (United Nations, 2015). In the next 37 years, Nigeria's population is estimated to outstrip that of the United States of America, placing the country as the third most populous country in the world. In addition and more worrisome is the unprecedented upsurge in population growth in a country with a perturbing poverty rate where the average life expectancy is 54.5 years and more than $90 \%$ of the population live on less than $\$ 2.00$ a day (Jorge, 20I4). The poverty profile reflects in the low life expectancy and constrains the population's access to clean and safe drinking water thereby putting the population at risk of water borne infections like diarrhea.

Diarrheal disease ranks 5th amongst the top 20 causes of death in Nigeria after Influenza \& Pneumonia, HIV/AIDS, Stroke, and Coronary/ Heart Disease (World Health Organization, 2015). This disease has proved to be the most fatal health challenge among children between the ages of 0-5 years. This situation calls for a speedy remedy as it presents a gamut of challenges. The most prominent among these is the inability to steadily pursue a program of eradicating poverty and inequality, to combat hunger and malnutrition, and to expand educational enrolment and health systems (Wilmoth, 20I5). This has culminated in complicating an already bad situation. If these strides which are crucial to the success of the sustainable development agenda are met, then the nation will be well positioned to reap the benefits of its optimally developed human resources.

In 2015, the African population recorded a youthful population, with children under the age of 15 accounting for $41 \%$ of the population while persons aged 15 to 24 accounted for a further $19 \%$ ((United NationsPublic Information Bureau, 20I5). After 3 years that situation has not changed. A total of $60 \%$ of Africa's population is aged between 0 and 24 and the future appears bleak if the current growth rate of population is not matched with adequate provision of basic amenities and food. If an integrated remedy is not sought within a short time frame, the implication is that in 2050, the nation may be plunged 
into a deep health crisis and poverty. The import of this strikes the need to kick-start a program of selfhelp that provides improved food crop productivity, potable water, health care, road and communication infrastructure, education and employment opportunities.

The government has the prerogative to put all these in place while prioritizing same as high profile goals for national development plan. This is more so as the national government is a signatory to the United Nations sustainable development goals (SDGs) and these goals, particularly goals three and six on preventing child and infant mortality and increasing the population's access to improved hygiene and sanitation, are sacrosanct for human development through the health pathway. In view of this, the Federal Ministry of Health introduced a national policy on integrated disease surveillance and monitoring. The disease surveillance program is a multi-faceted activity of both the State and Federal Ministry of Health. All primary, secondary and tertiary health facilities do keep up with regular and timely provision of disease data in the Local Government Areas (Federal Ministry of Health, 2008). One of such disease is gastroenteritis.

Gastroenteritis is the inflammation of the gastrointestinal tracts due to bacterial, viral, parasitic or fungal infections. The commonest of the causes is viral infection; rotavirus in children and norovirus and campylobacter in adults (Ciccarelli et al, 20/3). Transmission of gastroenteritis is due largely to eating improperly prepared foods, drinking contaminated water, or sharing of personal objects with an infected person. Common gastroenteritis manifestations include dysentery, typhoid fever, cholera and food poisoning (Amieva, 2005). Gastroenteritis patients generally may have symptoms of dehydration, loss of appetite, shock, nausea, vomiting, cramp, diarrhea and collapse (Liacouras and Markowitz, 1999; British Medical Association, 2002). Its indications are stomach and intestinal upsets resulting in watery stool caused by enteritis viruses, bacteria and heterotrophic organisms (BMA, 2002). Several forms of gastroenteritis exist and are caused by a variety of bacteria, bacterial toxins, viruses, protozoa and other organisms in water and food. Inflammation of the stomach and intestines in most patients infected with the disease can last for three (3) days or more and may lead to death if medical aid is not sought.

The disease affects all ages but the highest casualties are recorded among the 0-5 age cohort owing to their vulnerability and physiological makeup. Due to gastroenteritis infections, according to Ezechukwu (2008:7), "one out of every five Nigerian children may not live to see their fifth birthday". Akande (2017) stresses that infants have significantly lower body fluid than the average adult, and whenever they lose a little amount of body fluid as a result of gastroenteritis, they would have lost a good proportion of their total body fluid.

Between 2004 and 2008, incidents of gastroenteritis assumed a near epidemic proportion in Anambra State, South-East Nigeria and this necessitated a close monitoring by the State epidemiological surveillance team which sent in reports of observed cases and associated fatalities (Federal Ministry of Health, 2008). The reports raised serious concerns with respect to the spread of the disease across the state as nearly all the local government areas were affected except Anambra West, Awka North, Orumba North, Nnewi South, Anaocha and Oyi where the disease is controlled. This spatial variation in the number of reported cases of gastroenteritis and resulting deaths informed this study which aims at examining and mapping the trend of the disease and associated infant mortality in Anambra State. The study further investigates the various sources and quality of domestic water supply for the study localities. The UNICEF is at the fore front of providing safe drinking water in the rural parts of Anambra State due to the collapse of the Anambra State Water Corporation.

\section{Literature review and theoretical framework Literature review}

Assob et al (2018) investigated the general overview of disease burden in Africa. The study presented the trends of various diseases including viral, bacterial, parasitic, and fungal infections by country with emphasis on epidemiology, diagnostic, treatment, control strategies, WHO policies, and challenges. The role of the environment as a causative agent of the various communicable diseases was well highlighted in the study. The role of environmental determinants in non-communicable diseases was also shown in a study by O'Dell (1973). The study showed that in japan between 1953 and 1960, a large number of Japanese living in villages around Minamata Bay suffered neurological disease resulting in the death of over 100 persons. The disease was caused by the consumption of fish containing lethal amounts of mercury, which had accumulated in the fish and shellfish caught in that bay. The source of mercury was traced to a Vinylchloride and Acetyladehyde Plant that had used organic mercurials as catalysts and later dumped them as waste materials in the bay. The consumption of contaminated water is rife in many parts of the world especially in Sub-Saharan countries. For instance, the 2018 Multiple Cluster Survey report of the United Nations Childrens' Fund (UNICEF) indicates that about $90.80 \%$ of households 
in Nigeria had their sources of domestic water polluted by faeces and eschera coli specie.

Fletcher et al (20/3) used clinical and microbiological data to describe the clinical features of and pathogens associated with gastrointestinal illnesses in children who presented with diarrhea in two major public hospitals in Sydney for the period January 2007-December 2010. Of 825 children who tested positive for an enteric pathogen, 430 medical records were reviewed. Adenovirus, norovirus and rotavirus were identified in $20.8 \%, 20.3 \%$ and $21.6 \%$ of reviewed cases, respectively. The study also showed that younger children were more likely to have adenovirus and norovirus compared with rotavirus; and more viruses were detected in winter than in the other seasons. Rotavirus, according to the study, presented a distinct seasonal pattern with the lowest rates occurring in the warm months and peaking in the cooler months. Adenovirus showed a less consistent monthly trend, and norovirus detection increased in the cooler months. A decline in the number of rotavirus cases was observed after mid-2008. The study concluded that majority of the childhood diarrheal illnesses leading to hospital presentations in Sydney were caused by enteric viruses.

Fletcher et al (2015) further described the epidemiology of infectious gastrointestinal illnesses in Sydney, Australia. Patients with diarrhea or loose stools with an enteric pathogen detected were identified. Demographic, clinical and potential risk factor data were collected from their medical records and measures of association using descriptive and inferential statistics were conducted. The findings showed that Campylobacter $(22.0 \%)$ and Clostridium difficile (19.2\%) were the most frequently detected pathogens. Stratified analysis further showed that rotavirus $(22.4 \%)$, norovirus $(20.7 \%)$ and adenovirus (18.1\%) mainly affected children under 5 years while older children (5-12 years) were frequently infected with Campylobacter spp. (29.8\%) and nontyphoid Salmonella spp. (24.4\%).

In Nigeria, a study by Paul et al (1982) conducted over a 5-month period (September 1979 to January 1980), showed that rotaviruses were detected by counter immune-electrophoresis in the feces of 16 (I3.8\%) of I I 6 infants and young children between I and 48 months old with acute, sporadic gastroenteritis, at Ife, Nigeria. The highest frequency of rotavirus infection was found in the 7- to 12month age-group (18.9\%). Males constituted $61 \%$ of the sample and excreted rotavirus at a significantly higher rate than did females ( $P$ less than 0.01 ). Rotavirus infection was higher in the drier months of
November-January (19.3\%) than during the rainy months of September and October (8.5\%).

Nzeakor and Okafor (200l) in their study of bacterial enteropathogens and factors associated with seasonal episodes of gastroenteritis in Nsukka South East Nigeria agree that each year, during the rainy season between April and October, many children of school age and some young adults suffer from gastroenteritis. This period coincides with the flooding of manured farmlands after rainfall events. Between April and October (1996-1998), 500 loose or watery stools were collected from patients, the ages of which ranged from one month to 31 years. Drinking water and some fruit and vegetables prevalent during this period of the year also were cultured. Of the 500 stool samples tested, I38 $(27.6 \%)$ grew a range of organisms including Aeromonas hydrophila (65 [13\%]), Salmonella spp. (55 [11\%]), Shigella spp. (9 [1.8\%]) and enteropathogenic Escherichia coli ( 9 [1.8\%]). Drinking water and some vegetables grew Pseudomonas aeruginosa and Enterococcus faecalis, respectively. The highest isolation rate occurred during June and July, corresponding to the period of greatest flooding of arable land. Although no enteropathogens were isolated from the fruit and vegetables examined, they contained $\mathrm{E}$. faecalis - an organism found in faeces. Their findings failed to explain why $72 \%$ of the samples grew no bacterial enteropathogens.

Fagbami, Johnson and David-West (1985) studied rotavirus infection in children presenting with acute gastroenteritis in Ibadan, South West Nigeria. Faecal samples from 84 children presenting with acute gastroenteritis at the University College Hospital, Ibadan, Nigeria and 28 from a non-diarrhoeal control group were tested for rotavirus by an ELISA. 18 cases $(21 \%)$ and none of the controls were positive. Hospital in-patients had a higher percentage of positives (25\%) than did out-patients (10\%). The age distribution of infections showed that the highest infection rate $(67 \%)$ occurred in children four to six months old. Percentages of positive samples from other age groups were as follows: 0 to 3 months, 13\%; 7 to 12 months, $33 \%$; and 13 to 24 months, $16 \%$. None of the faecal extracts from children older than two years was positive for rotavirus.

Ayolabi (2010) in her study on isolation and molecular characterization of some viruses associated with gastroenteritis has shown that acute viral gastroenteritis is the leading cause of morbidity and mortality among children under five years old, particularly in the developing countries. However, little is known about these viral pathogens associated with gastroenteritis in Nigeria. In order to provide baseline data on the prevalence and strains of these 
viral agents associated with acute gastroenteritis, a hospital based cross sectional study was conducted in Lagos, Nigeria. Three hundred and two (302) stool specimens from diarrhea patients and sixty-four (64) stool specimens from non-patients (control) underfive years were collected between August 2006 and July 2008. The samples were screened for rotaviruses, astroviruses, human adenoviruses and noroviruses using Enzyme immunoassay (EIA) technique. Viral particles were confirmed by transmission electronmicroscopy (TEM). Molecular studies were carried out on the genetic diversity of rotaviruses and noroviruses isolates using Polyacrylamide gel electrophoresis. Prevalence of $25.8 \%, 37.3 \%, 40.4 \%$ and $8.7 \%$ were recorded for rotavirus, norovirus, astrovirus and adenovirus respectively in the samples tested. There was a $25 \%$ rate of mixed infection observed between rotavirus and other enteric viruses. Prevalence was more in males than in females and also in age group $6-12$ months for most of the viral isolates. Rotavirus occurred throughout the year with a higher incidence occurring in the drier months (October -March) and peak incidences were observed in February and December of the sampled period.

Orji (2017) reported the treatment of 250 cases of gastroenteritinal cases by the University of Nigeria Teaching Hospital and Enugu State University of Technology between January-June 2017. While in some cases bacterial assays have been used to identify the causative bacteria by the use of endoscopy machines which made scanning of intestinal and visceral body parts easier and at the same time accelerating the speed of diagnosis. This method makes treatment faster, cheaper and more effective. The hospital did acquire the endoscope machine to diagnose and manage the issue of gastroenterology as critical cases were referred abroad and the poor patients suffered greatly from acute infections and eventual loss of life especially among the age group of 0-5years.

\section{Theoretical framework}

The Public Administration Insights Theory (Rinquist, 1995) is employed as the theoretical framework for this study. This framework puts it as a duty upon government and voluntary health agencies to engage in discovering the link between water quality and incidences of water-borne diseases within the ambit of water-related practices of the people consuming the water from specified sources. In this regard, this work is directed at discovering the relative importance of the identified causes of gastroenteritis infection in children in the study area. Mapping the causes to the reported cases and deaths associated with the disease, a relationship between the causative disease germs and the study area can be established. This posits that the study area is seen as a system of constituencies linked by a common problem related to the presence or absence of the causative factors of gastroenteritis.

Studies in ensuring safe drinking water is predicated on the identification and elimination of the basic causes of contaminated water. The methods and strategies of combating these contaminants are diverse and holistic in nature. A number of models exist and include the Vibration Sum Frequency Generation Model which explains water quality from the perspective of the effects of hydrogen ion bondings into a regular bonded network. The Dempster-Schafer Theory of Evidence advocates the use of a risk contour of contaminants infusion to identify the sensitive locations of contaminants in the water distributive network. The term 'contaminants' is used to mean all forms of chemical, physical and biological pathogens (Rehan, Yehuda and Balvant, 2006).

The Public Administration Insights Theory (Rinquist, 1995) advocates water quality evaluation funded and executed as a matter of public policy. This model finds application within the United States of America and in most other countries. In the U.S.A. under the Water Quality Act of 1967, a move was made to develop a National Standards for Drinking Water Quality benchmark. In this light water samples are collected and tested for contamination. This model is adopted as the framework for this study because of the general concern of the health service community for the elimination of gastroenteritis which is a water-borne disease.

\section{Methodology \\ Data sources and collection}

Anambra State, Nigeria, where the study was conducted is located in the South-East geopolitical zone of Nigeria alongside Abia, Ebonyi, Enugu and Imo States. On its western boundary lies the River Niger which serves directly or indirectly, through its tributaries, as the source of domestic water supply to many of the communities in the State. The study adopted the use of both primary and secondary data. The primary data was by extensive field work to ascertain the sources of domestic water accessed by the study communities while the secondary data were sourced from government records. Such datasets from government records are reliable because of the care exercised by the relevant agencies in their collection as field personnel are trained and well-paid to ensure the completeness and accuracy of the datasets which are used for planning and research by the government. The report on infant gastroenteritis cases and deaths by the 
Anambra State Integrated Disease Surveillance and Response Team for the period 2004 - 2008 constituted the secondary datasets.

\section{Data analysis}

Data on the major sources and level of contamination of water supply in each Local Government Area were analyzed in the laboratory while descriptive statistics and Multiple Linear Regression were used to analyze the disease data. The dependent and set of independent variables for the regression analysis were number of deaths and forms of bacterial indicators respectively. The regression analysis was performed with the aid of the Statistical Package for Social Sciences, version 20.

Further, a cluster analysis was carried out to classify the local government areas into groups or spatial units in terms of closeness of member units in each cluster. The cluster analysis is able to select the taxonomic units of the closest relationship and likeliness. In classification, a taxonomic unit is not able to belong to two groups but to one group where it is by the combination of all its attributes related to the members of the group to which it belongs. The likeliness effect of the consideration of the aggregate of the attributes is seen in the similarity matrix and the coefficients of the attributes. This eliminates every effect of a parsimonious evaluation of the sizes of the attributes but advances the aggregate of the attributes. Essentially, the cluster analysis was used here in the mapping of the spatial pattern of the variables that have been identified as causing gastroenteritis and the associated fatalities. The investigation was run at two levels. The first was to seek out the relationship of the number of cases to the deaths recorded while the second was to investigate the relationship between the causative disease groups and the deaths.

\section{Results}

For the period under review, about 58,269 cases of infant gastroenteritis disease were reported in the entire State with 178 deaths as shown in Table I. Idemili South recorded the highest infant mortalities during the period while 6 local government areas had no infant mortality. These were Anambra West, Anaocha, Awka North, Nnewi South, Orumba North and Oyi. From Table I, the total infant gastroenteritis cases increased over the years except in 2006, with 8,584 cases. For the periods of 2004, 2005, 2007 and 2008 , reported cases were $9,948,1 \mathrm{I}, 549,12,870$ and 15,318 respectively. The spatial distribution of the reported cases and deaths is illustrated in Figures I 5.

Table I: Cases and deaths of gastroenteritis in Anambra State (2004-2008)

\begin{tabular}{|c|c|c|c|c|c|c|c|c|c|c|c|}
\hline \multirow{2}{*}{$\mathrm{S} /$} & \multirow[t]{2}{*}{ LGA } & \multicolumn{2}{|l|}{2004} & \multicolumn{2}{|l|}{2005} & \multicolumn{2}{|l|}{2006} & \multicolumn{2}{|l|}{2007} & \multicolumn{2}{|l|}{2008} \\
\hline & & $\begin{array}{l}\text { Case } \\
\mathrm{s}\end{array}$ & $\begin{array}{l}\text { Deat } \\
\mathrm{h}\end{array}$ & $\begin{array}{l}\text { Case } \\
\text { s }\end{array}$ & $\begin{array}{l}\text { Deat } \\
\mathrm{h}\end{array}$ & $\begin{array}{l}\text { Case } \\
\text { s }\end{array}$ & $\begin{array}{l}\text { Deat } \\
\mathrm{h}\end{array}$ & $\begin{array}{l}\text { Case } \\
\text { s }\end{array}$ & $\begin{array}{l}\text { Deat } \\
\mathrm{h}\end{array}$ & $\begin{array}{l}\text { Case } \\
\text { s }\end{array}$ & $\begin{array}{l}\text { Deat } \\
\mathrm{h}\end{array}$ \\
\hline I & AGUATA & 662 & 0 & 992 & I & 645 & 2 & 679 & I & 1060 & 20 \\
\hline 2 & ANAMBRA EAST/WEST & 367 & 2 & 240 & 0 & 324 & 0 & 830 & 1 & 1140 & 3 \\
\hline 3 & $\begin{array}{l}\text { ANAOCHA/DUNUKO } \\
\text { FIA } \\
\text { /NJIKOKA }\end{array}$ & 1082 & 6 & 1023 & I & 767 & 0 & 1254 & 4 & 1146 & 13 \\
\hline 4 & $\begin{array}{l}\text { AWKA } \\
\text { NORTH/SOUTH }\end{array}$ & 1209 & 0 & 1232 & 3 & 757 & 0 & 278 & 0 & 931 & 4 \\
\hline 5 & OYI / AYAMELUM & 579 & 0 & 1103 & 0 & 1017 & 0 & 1066 & 2 & 869 & 2 \\
\hline 6 & $\begin{array}{l}\text { IDEMILI } \\
\text { NORTH/SOUTH }\end{array}$ & 507 & 0 & 847 & 2 & 679 & 4 & 988 & 10 & 1744 & 23 \\
\hline 7 & IHIALA & 298 & 3 & 289 & 1 & 316 & 2 & 640 & 0 & 575 & 11 \\
\hline 8 & $\begin{array}{l}\text { EKWUSIGO/NNEWI } \\
\text { NORTH/SOUTH }\end{array}$ & 490 & 0 & 1210 & 2 & 588 & 0 & 2264 & 0 & 3237 & 6 \\
\hline 9 & OGBARU & 492 & 0 & 372 & 0 & 434 & 0 & 476 & 0 & 639 & 5 \\
\hline 10 & $\begin{array}{l}\text { ONITSHA } \\
\text { NORTH/SOUTH }\end{array}$ & 3286 & 0 & 2947 & 3 & 1608 & 1 & 1667 & 10 & 1636 & 14 \\
\hline 11 & $\begin{array}{l}\text { ORUMBA } \\
\text { NORTH/SOUTH }\end{array}$ & 976 & 8 & $|54|$ & 0 & 958 & 0 & 1754 & 0 & 2341 & 8 \\
\hline & TOTAL & 9948 & 19 & $\begin{array}{l}1154 \\
9\end{array}$ & 13 & 8584 & 9 & $\begin{array}{l}1287 \\
0\end{array}$ & 28 & $\begin{array}{l}\mid 531 \\
8\end{array}$ & 109 \\
\hline
\end{tabular}

Source: Compiled from Epidemiological Unit, Anambra State Ministry of Health, Awka 


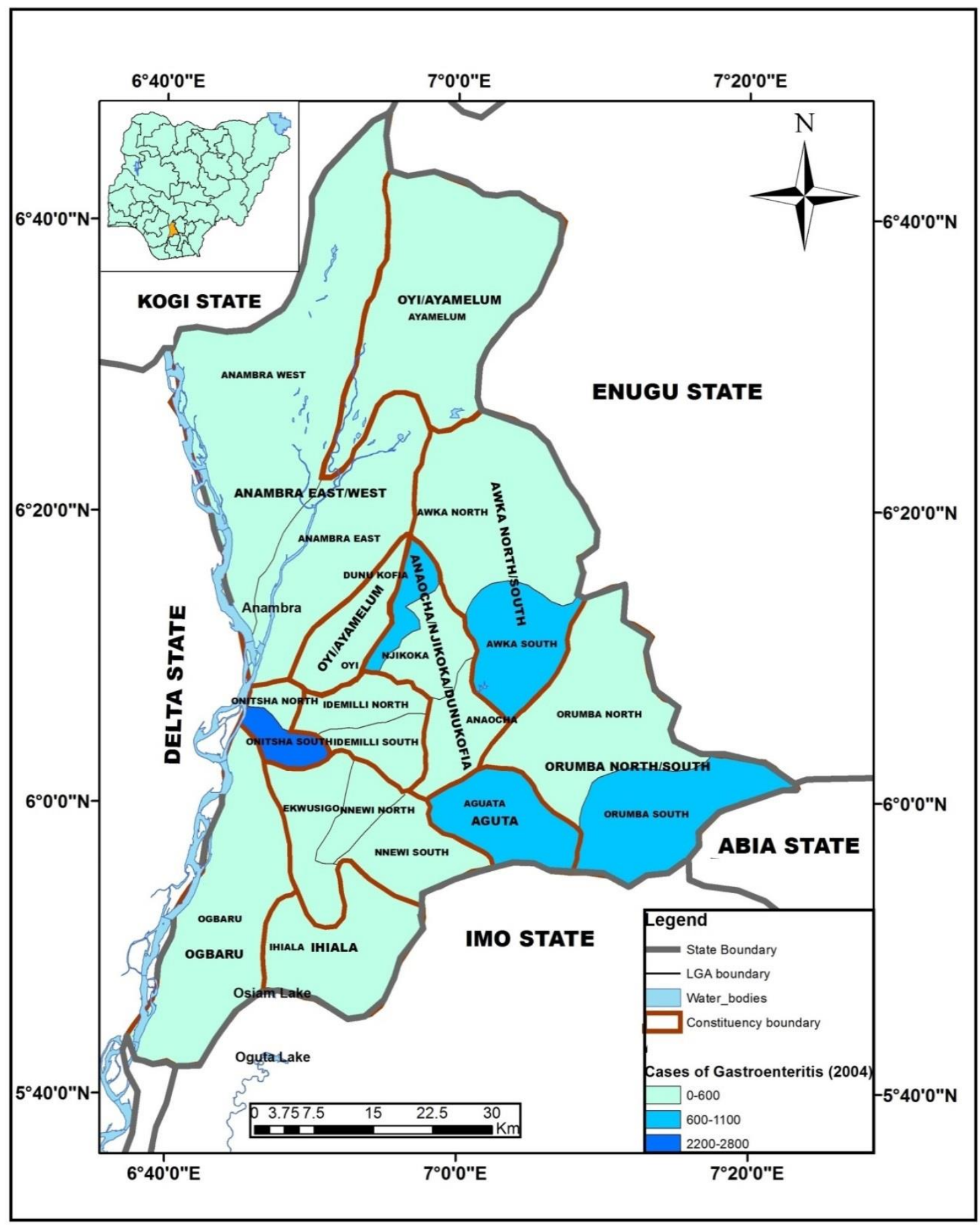

Fig Ia: Cases of gastroenteritis (2004) 


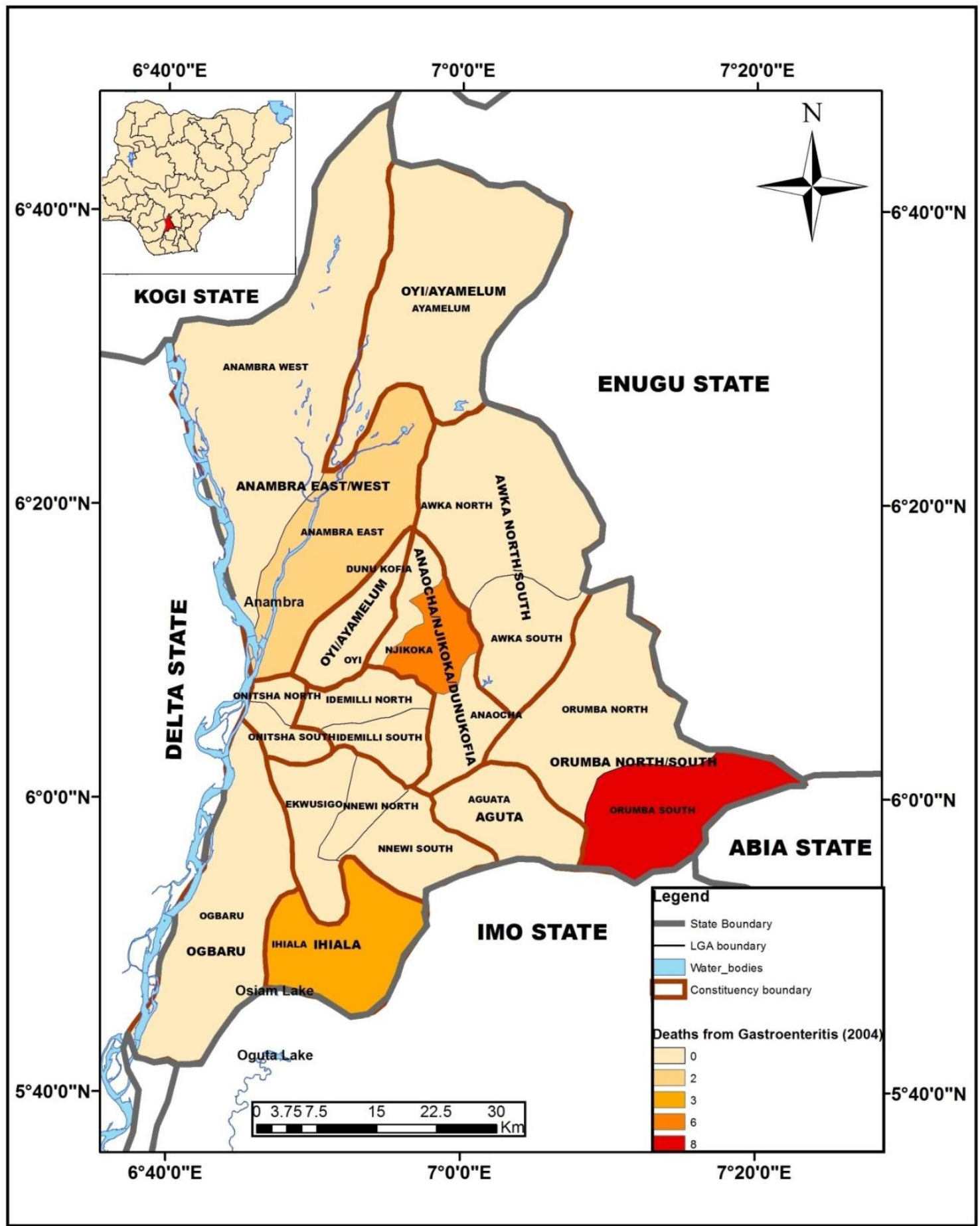

Fig Ib: Deaths from gastroenteritis (2004) 


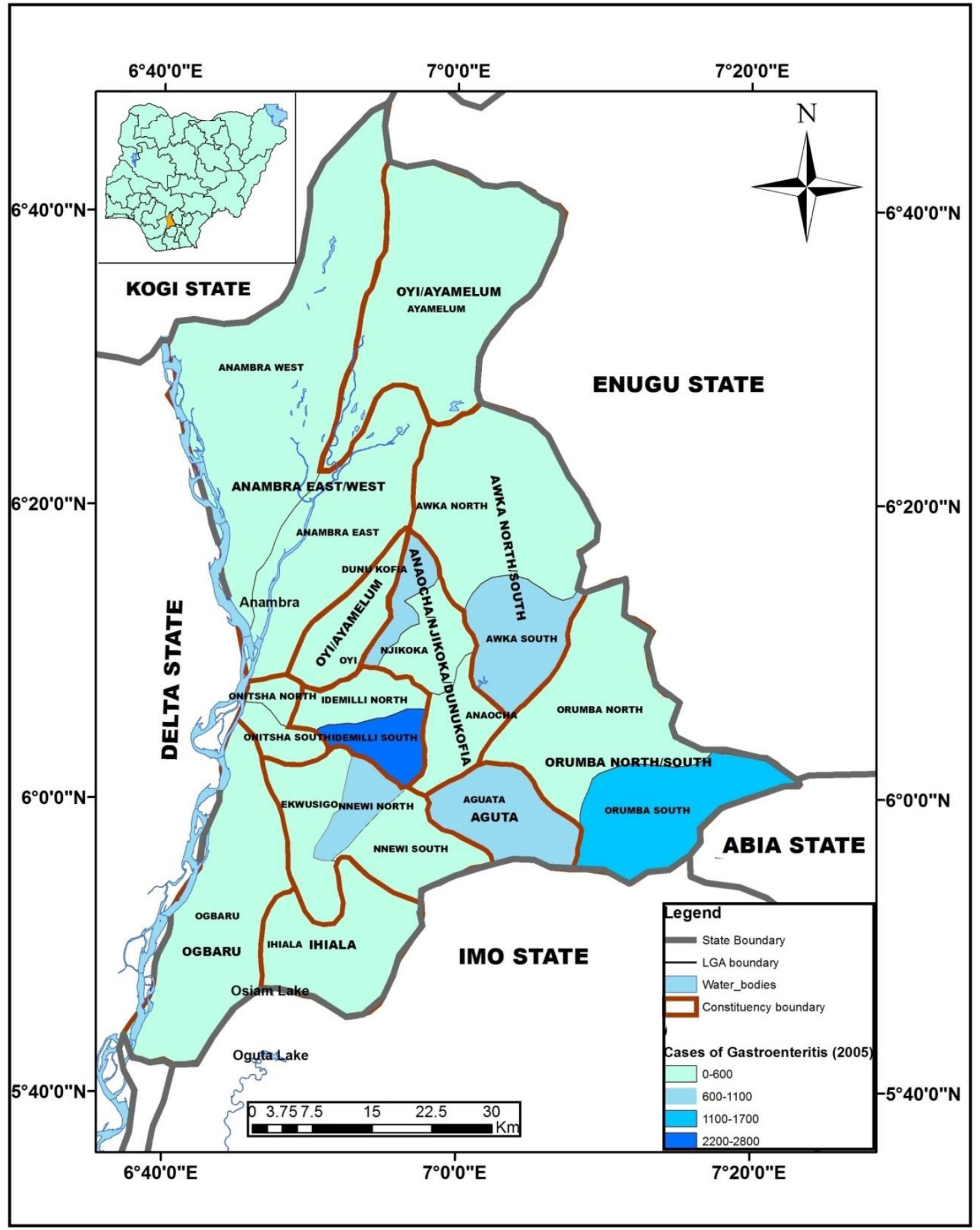

Fig 2a: Cases of gastroenteritis (2005) 


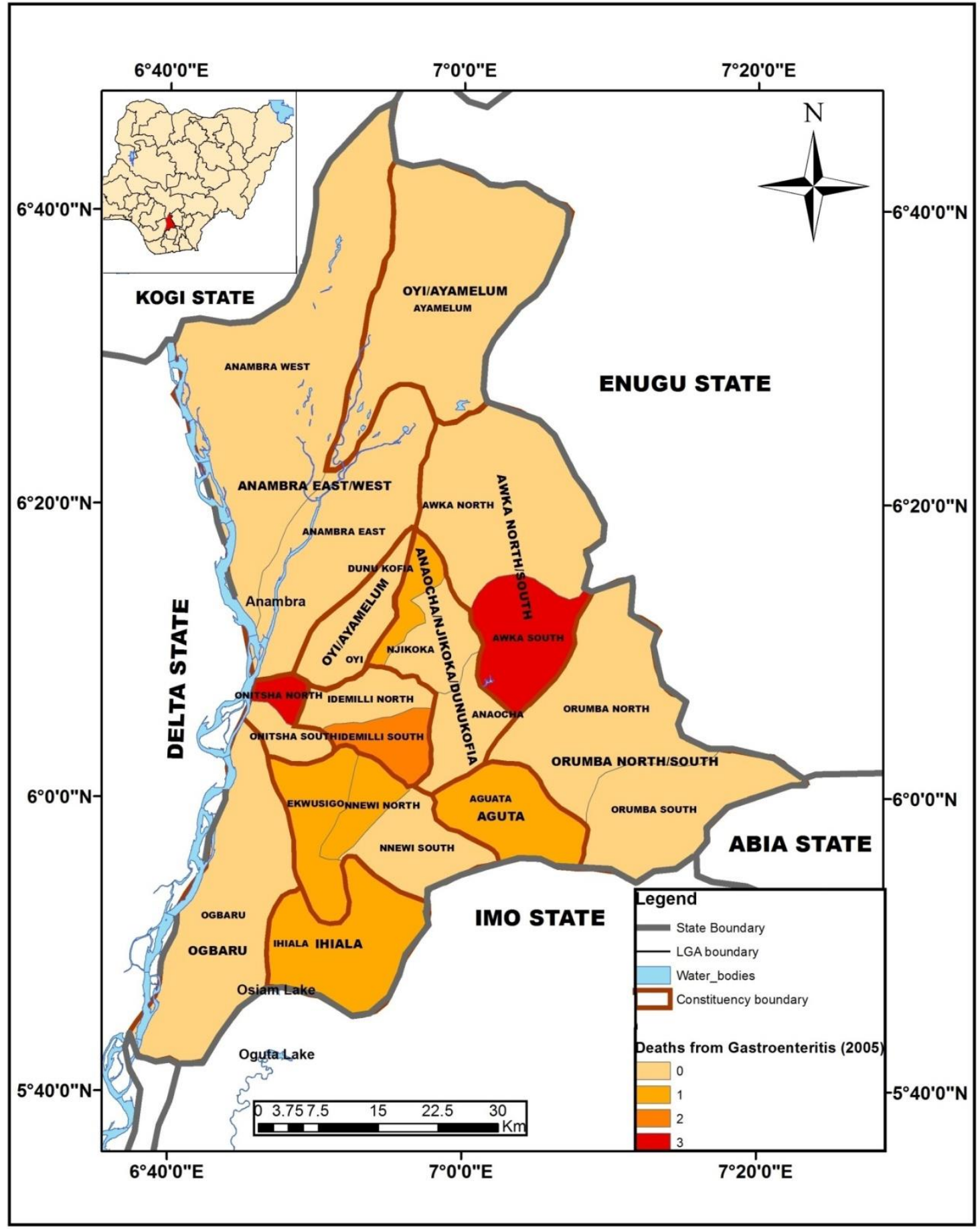

Fig 2b: Deaths from gastroenteritis (2005) 


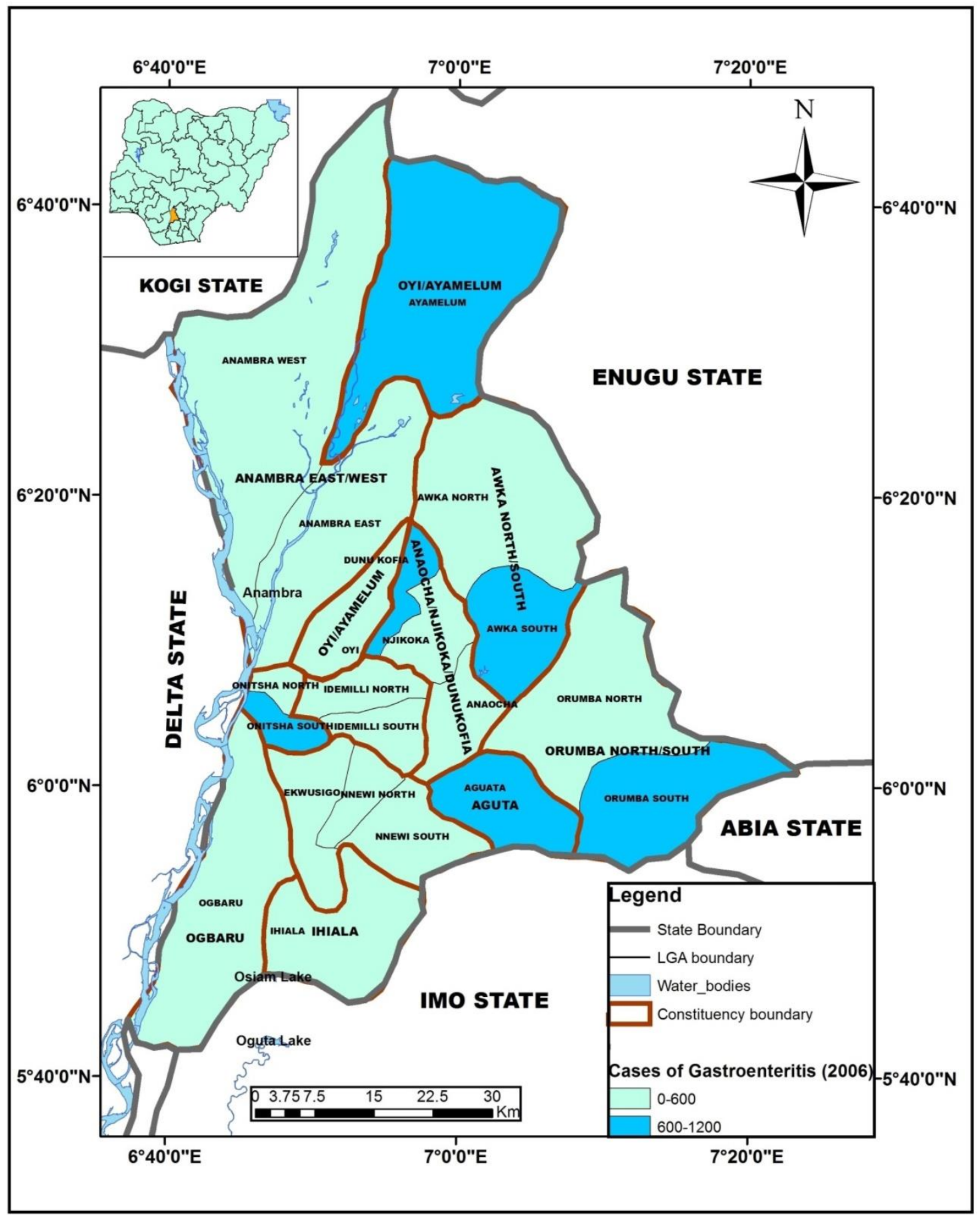

Fig 3a: Cases of gastroenteritis (2006) 


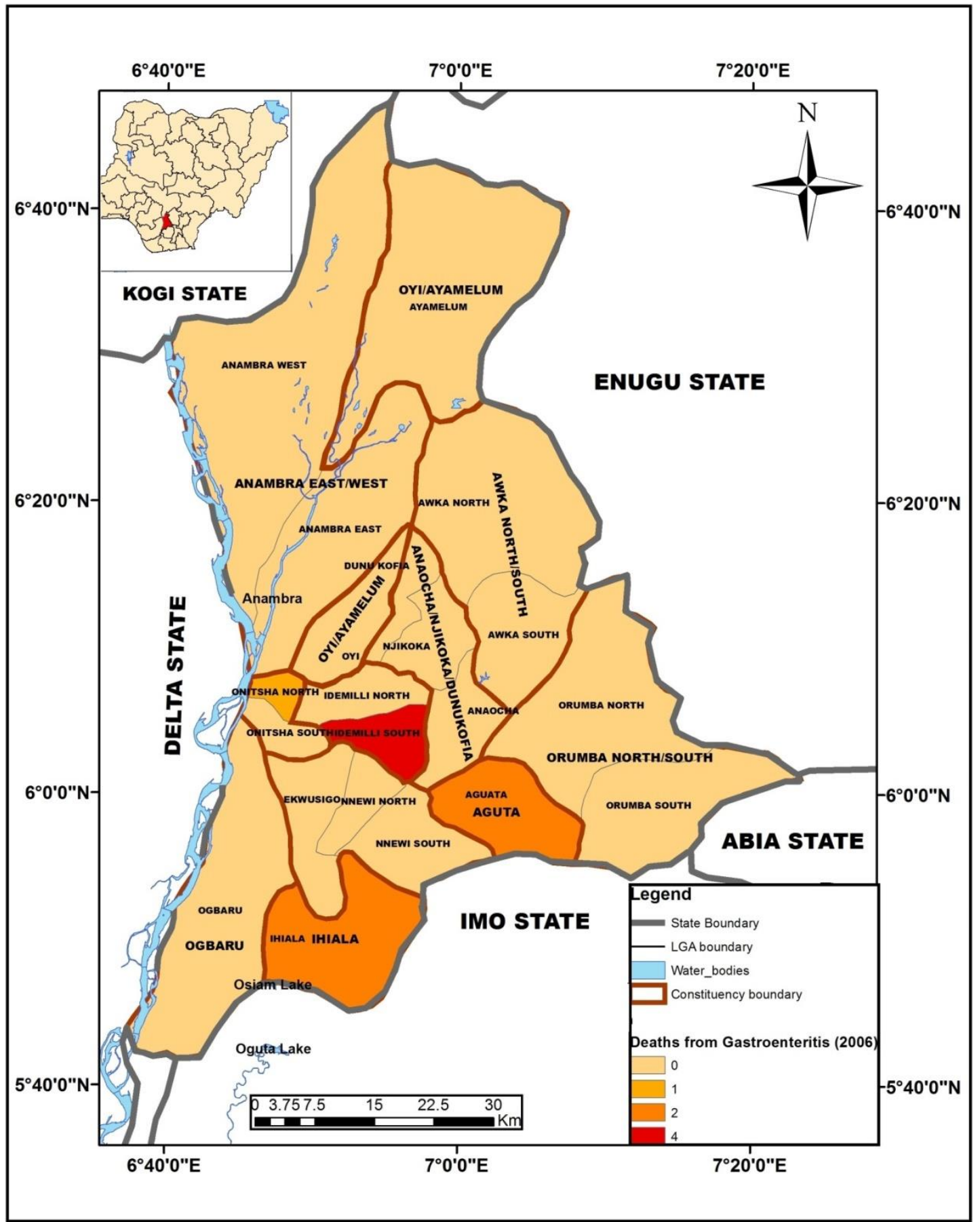

Fig 3b: Deaths from gastroenteritis (2006) 
African Population Studies Vol 32, No 2, (Supp. 2), Sept. 2018

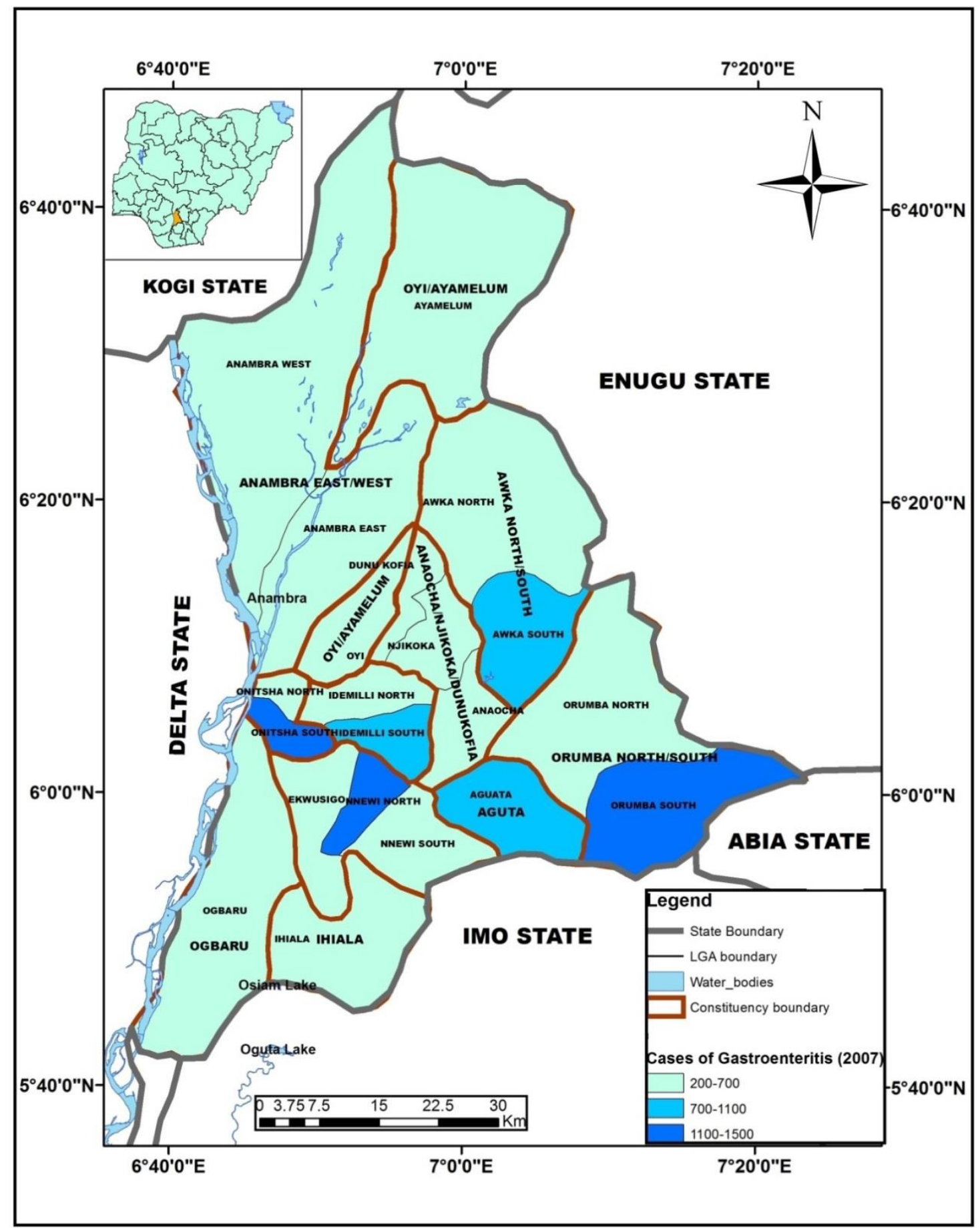

Fig 4a: Cases of gastroenteritis (2007) 


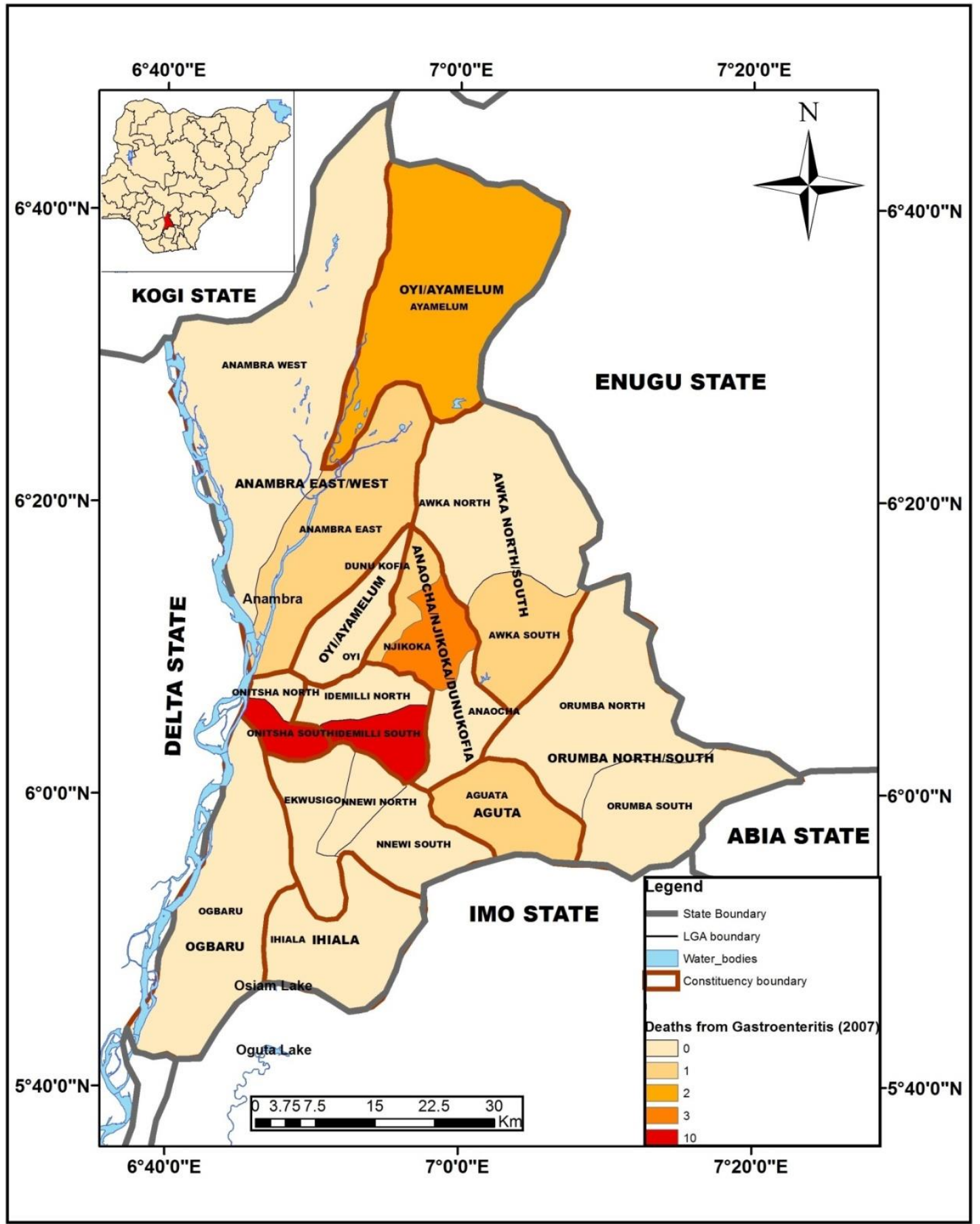

Fig 4b: Deaths from gastroenteritis (2007) 


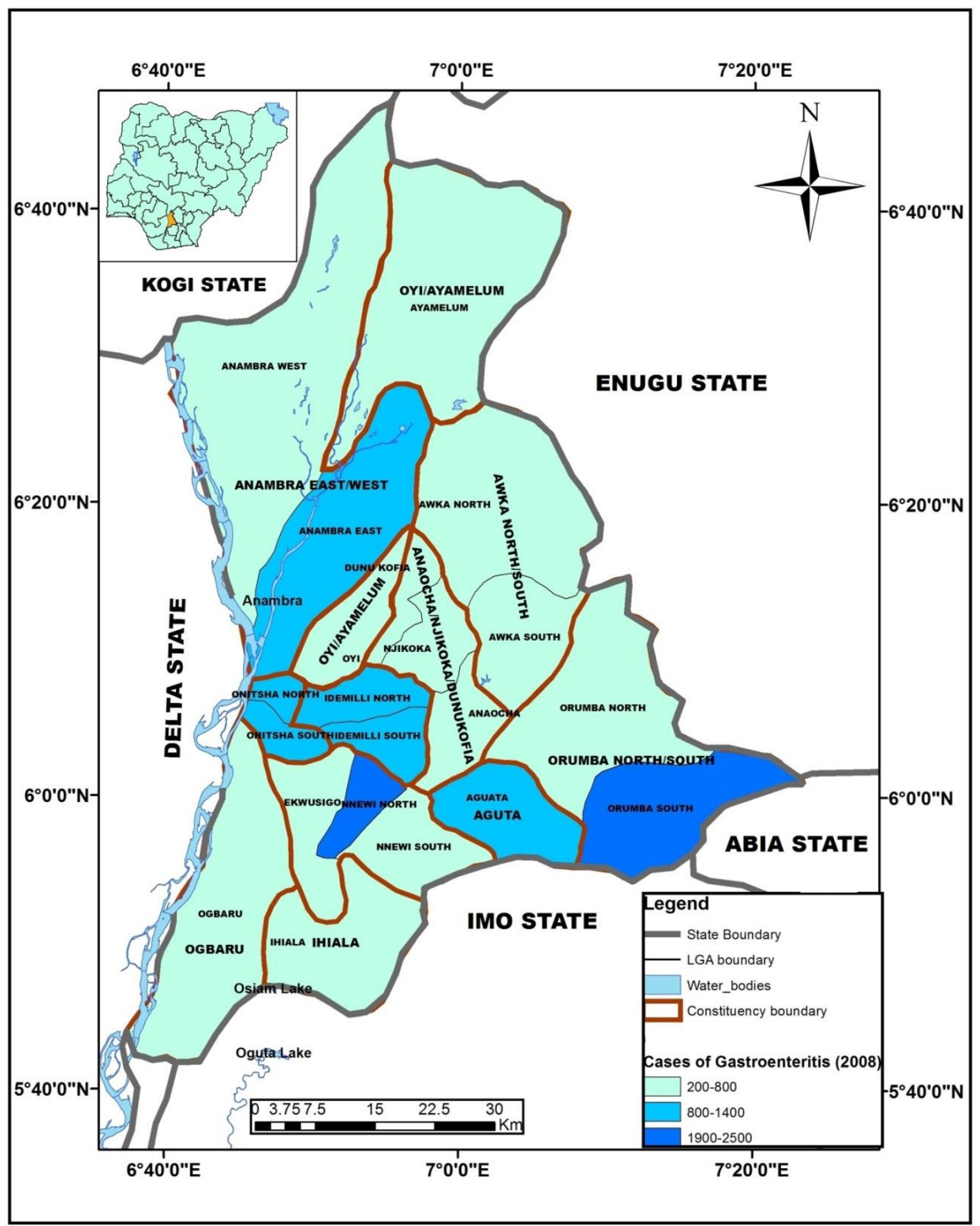

Fig 5a: Cases of gastroenteritis (2008) 


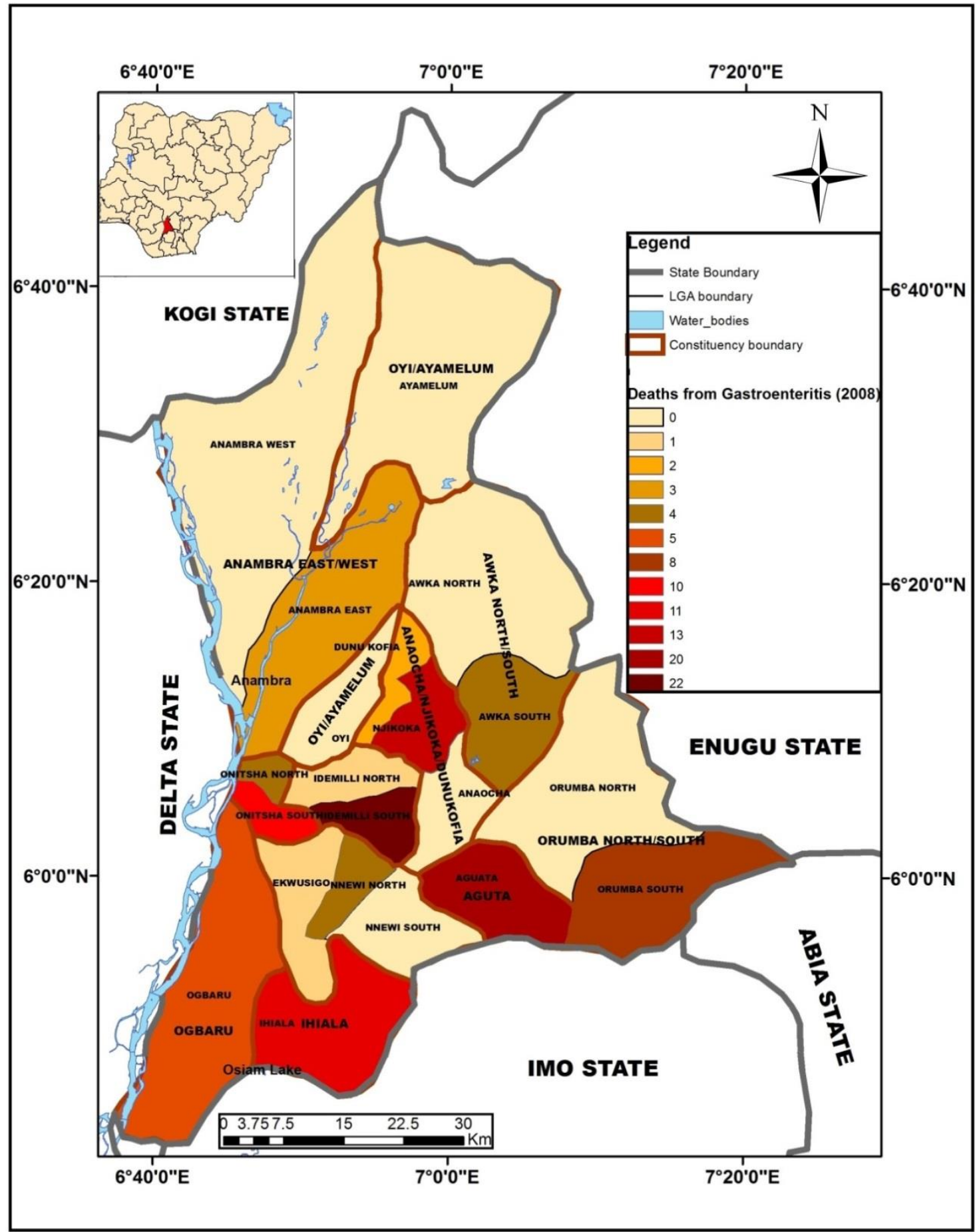

Fig 5b: Deaths from gastroenteritis (2008)

The highest numbers of recorded cases of infection are in this order; in 2004, Onitsha North/South constituency recorded 3,286 cases the highest number in that year. In 2005 the same constituency recorded the highest number of cases with a figure of 2,947. In 2006 the highest number of persons infected with gastroenteritis was also recorded in Onitsha North/South constituency with 1,608. The highest record for 2007 cases was in Ekwusigo/Nnewi North/South constituency. A total of 3,237 deaths in Ekwusigo/ Nnewi North/South constituency was the highest value for gastroenteritis infection in the State for the year 2008.
In 2004, 19 deaths were recorded from the disease across constituencies as follows; 8 deaths in Orumba North South constituency, 6 in Anaocha/Njikoka/Dunukofia constituency, 3 in Ihiala constituency and 2 in Anambra East/West constituency. In 2005 a total number of 12 deaths occurred across 6 constituencies namely; Awka North/South and Onitsha North/South-3 each, 2 deaths recorded for Idemili North/South constituency, 4 deaths in each of these four constituencies namely Ihiala, Ekwusigo/NnewiNorth/South, Aguata and Anaocha/Njikoka/Dunukofia. In 2006, a total of 7 
deaths were recorded in this manner, 4 deaths were recorded in Idemili North/South constituency.

In 2007, a total of 28 deaths were recorded with the highest casualties of 10 deaths each, recorded in two constituencies, Onitsha North/South and Idemili North/South. In 2008 the cumulative deaths resulting from gastroentritis infection is 109 with its peak record of 23 deaths in Idemili North/South constituency, 20 deaths each in Aguata and Orumba North/South constituencies, 13 deaths in Anaocha/Njikoka/Dunukofia constituency with all casualities indicated at Njikoka LGA. 14 deaths were recorded in Onitsha North/South constituency while Ihiala constituency recorded 10 deaths Ogbaru 5, Ekwusigo/NnewiNorth/South 6, Orumba 8, Anambra
East/West 3, Awka North/South 4, Oyi/Ayamelum 3, from gastroentritis infection. The other LGAs with noticeable infant mortality arising from gastroenteritis disease are Ihiala, Onitsha South and Orumba South, with percentage deaths of $9.82,8.93$ and 7.14 percent respectively.

The result of the cluster analysis of the spatial pattern of reported cases and deaths shows four clusters. The first cluster had Onitsha South, Idemili South, Njikoka, Ihiala, Aguata and Orumba South LGAs while cluster three had Awka North LGA. The fourth cluster had only Ayamelum LGA while the other remaining 13 LGAs belonged to cluster two as illustrated in Figure 6.

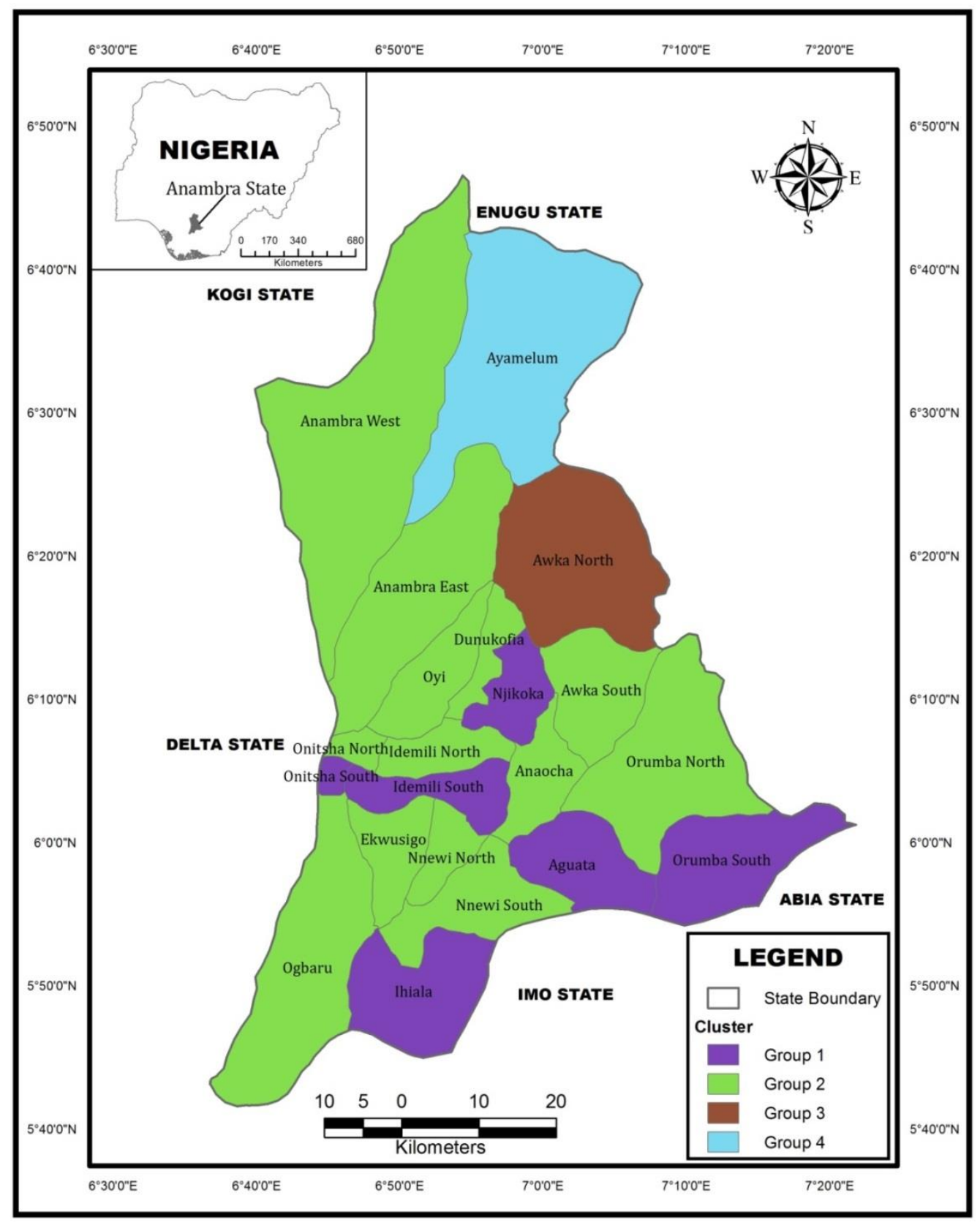

Fig 6: Cluster analysis of the prevalence of gastroenteritis 
The results of the Multiple Regression showed a linear relationship between infant deaths resulting from gastroenteritis infections and the bacteria indicators from various domestic water sources commonly available in the constituencies. The water samples were collected in all LGAs in the State and their level of bacterial contamination was measured likewise. These water sources include spring, stream, rivers, shallow wells and water vendors. The water samples were tested for aerobic heterotrophic count (AC), total coliform (TC), feacal coliform (FC) and enterococci (EN). The results are presented in Table 2. While the regression equations for each of the constituencies are shown in Table 3, the regression equation for the whole state is presented as;

$y=3.76+1.99(\mathrm{AC})+1.13(\mathrm{TC})+2.81(\mathrm{FC})$ $+\mathrm{I} .78(\mathrm{EN})$

Table 2:Major sources of water supply and their levels of indicator bacteria in the 2I LGAs of Anambra State

\begin{tabular}{|c|c|c|c|c|c|c|c|}
\hline \multirow[t]{2}{*}{$\mathrm{S} / \mathrm{N}$} & \multirow[t]{2}{*}{ LGAs } & \multirow{2}{*}{$\begin{array}{l}\text { major } \\
\text { sources of } \\
\text { water* }\end{array}$} & \multicolumn{5}{|c|}{ +Average Total Heterotrophic and Indicator bacteria 2004 - 2008} \\
\hline & & & $\begin{array}{l}\text { Aerobic } \\
\text { heterotrophic } \\
\text { count } \\
(\mathrm{cfu} / 1000 \mathrm{ml} \mathrm{CA})\end{array}$ & $\begin{array}{l}\text { Total } \\
\text { coliform } \\
\text { (TC) } \\
(\mathrm{cfu} / 100 \mathrm{ml})\end{array}$ & $\begin{array}{l}\text { Feacal } \\
\text { coliform } \\
(\mathrm{FC}) \\
(\mathrm{cfu} / 100 \mathrm{ml})\end{array}$ & 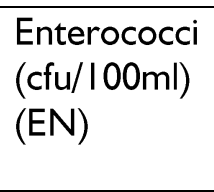 & $\begin{array}{l}\text { No } \\
\text { of } \\
\text { deaths }\end{array}$ \\
\hline 1 & Aguata & Stream & $>500$ & 49 & 8 & 6 & 20 \\
\hline 2 & Anambra East & Stream & $>400$ & 36 & 6 & 2 & 3 \\
\hline 3 & $\begin{array}{l}\text { Anambra } \\
\text { West }\end{array}$ & $\begin{array}{l}\text { Shallow } \\
\text { Well }\end{array}$ & 288 & 15 & 1 & I & 0 \\
\hline 4 & Anaocha & $\begin{array}{l}\text { Shallow } \\
\text { Well }\end{array}$ & 164 & 16 & 3 & I & 0 \\
\hline 5 & Awka North & River & 415 & 92 & 14 & 6 & 0 \\
\hline 6 & Awka North & $\begin{array}{l}\text { Shallow } \\
\text { Well }\end{array}$ & 388 & 38 & 4 & 2 & 4 \\
\hline 7 & Ayamelum & $\begin{array}{l}\text { Shallow } \\
\text { Well }\end{array}$ & $>210$ & 10 & 82 & I & 2 \\
\hline 8 & Dunukofia & $\begin{array}{l}\text { Shallow } \\
\text { Well }\end{array}$ & 371 & 20 & 3 & 4 & 2 \\
\hline 9 & Ekwusigo & $\begin{array}{l}\text { Shallow } \\
\text { Well }\end{array}$ & 390 & 15 & 2 & 2 & 2 \\
\hline 10 & Idemili North & $\begin{array}{l}\text { Shallow } \\
\text { Well }\end{array}$ & 162 & 16 & 2 & 4 & I \\
\hline 11 & Idemili South & $\begin{array}{l}\text { Shallow } \\
\text { Well }\end{array}$ & 474 & 48 & 10 & 5 & 22 \\
\hline 12 & Ihiala & Stream & $>400$ & 32 & 8 & 5 & 11 \\
\hline 13 & Njikoka & $\begin{array}{l}\text { Water } \\
\text { Vendor }\end{array}$ & 450 & 20 & 10 & 6 & 13 \\
\hline 14 & Nnewi North & $\begin{array}{l}\text { Water } \\
\text { Vendor }\end{array}$ & 380 & 16 & 7 & 2 & 4 \\
\hline 15 & Nnewi South & $\begin{array}{l}\text { Shallow } \\
\text { Well }\end{array}$ & 439 & 24 & 3 & I & 0 \\
\hline 16 & Ogbaru & River & $>450$ & 54 & 6 & 3 & 5 \\
\hline 17 & Onitsha North & $\begin{array}{l}\text { Water } \\
\text { Vendor }\end{array}$ & 324 & 24 & 5 & 2 & 4 \\
\hline 18 & Onitsha South & $\begin{array}{l}\text { Water } \\
\text { Vendor }\end{array}$ & 393 & 18 & 10 & 6 & 10 \\
\hline 19 & $\begin{array}{l}\text { Orumba } \\
\text { North }\end{array}$ & Spring & 220 & 25 & 6 & 4 & 0 \\
\hline 20 & $\begin{array}{l}\text { Orumba } \\
\text { South }\end{array}$ & Stream & 408 & 28 & 5 & 4 & 8 \\
\hline 21 & Oyi & Shallow & 160 & 16 & 5 & 2 & 0 \\
\hline
\end{tabular}




\begin{tabular}{|l|l|l|l|l|l|l|}
\hline & Well & & & & & \\
\hline & $\begin{array}{l}\text { WHO 2004 } \\
\text { standard } \\
\text { drinking water }\end{array}$ & & $>300$ & 10 & 0 & 0 \\
\hline
\end{tabular}

Source: Authors Analysis

Table 3: Regression Line Equations for number of deaths in 21 LGAs of Anambra State

\begin{tabular}{|c|c|}
\hline Aguata & $y=2.02+0.72(A C)+1.92(T C)+1.61(F C)+0.96(E N)$ \\
\hline Anambra East & $y=3.71+0.23(A C)+0.42(T C)+0.5 I(F C)+0.29(E N)$ \\
\hline Anambra West & $y=2.48+0.84(A C)+0.11(T C)+0.19(F C)+0.20(E N)$ \\
\hline Anaocha & $y=1.59+0.23(A C)+0.63(T C)+0.55(F C)+0.82(E N)$ \\
\hline Awka North & $y=1.88+0.87(A C)+1.02(T C)+0.93(F C)+0.75(E N)$ \\
\hline Awka North & $y=2.09+0.89(A C)+0.91(T C)+0.63(F C)+0.88(E N)$ \\
\hline Ayamelum & $y=2.44+0.74(A C)+0.76(T C)+0.51(F C)-0.8 I(E N)$ \\
\hline Dunukofia & $y=3.04+0.92(A C)+0.97(T C)+0.64(F C)+0.66(E N)$ \\
\hline Ekwusigo & $y=3.65+0.84(A C)+0.91(T C)+0.5 I(F C)+0.92(E N)$ \\
\hline Idemili North & $y=1.09+2.22(A C)+1.12(T C)+0.84(F C)+0.73(E N)$ \\
\hline Idemili South & $y=2.44+2.67(A C)+1.81(T C)+1.62(F C)+1.09(E N)$ \\
\hline Ihiala & $y=1.82+0.94(A C)+0.69(T C)+0.73(F C)+0.8 I(E N)$ \\
\hline Njikoka & $y=2.08+0.79(A C)+0.49(T C)+0.88(F C)+0.72(E N)$ \\
\hline Nnewi North & $y=3.05+0.81(A C)+0.98(T C)+0.81(F C)+0.90(E N)$ \\
\hline Nnewi South & $y=2.07+0.77(A C)+0.70(T C)+0.48(F C)+0.62(E N)$ \\
\hline Ogbaru & $y=1.84+0.85(A C)+1.5 I(T C)+0.91(F C)+0.70(E N)$ \\
\hline Onitsha North & $y=2.67+0.90(A C)+1.01(T C)+0.79(F C)+0.83(E N)$ \\
\hline Onitsha South & $y=3.48+0.76(A C)+1.71(T C)+0.94(F C)+0.59(E N)$ \\
\hline Orumba North & $y=2.77+0.90(A C)+0.66(T C)+0.7 I(F C)+0.84(E N)$ \\
\hline Orumba South & $y=3.22+0.87(A C)+0.81(T C)+0.67(F C)+0.77(E N)$ \\
\hline Oyi & $y=1.98+0.19(A C)+0.01(T C)+0.11(F C)+0.20(E N)$ \\
\hline
\end{tabular}

Anambra State $y=3.76+1.99(\mathrm{AC})+1.13(\mathrm{TC})+2.8 \mathrm{I}(\mathrm{FC})+1.78(\mathrm{EN})$

Source: Authors Analysis

\section{Discussion}

In Aguata a total of 20 deaths within the period were recorded. The variable disposition shows a unit increase in Aerobic heterotrophic bacteria count which is linked with 2.22 rate of increase in deaths under the assumption that other variables are held constant. Each of the other independent variables shows a unit increase in deaths. Total coliform and enteroccoci thus generated $\mathrm{I} .6 \mathrm{I}$ and 0.96 increase in deaths respectively. A disturbing revelation was observed in Idemili South with a record of 22 deaths. Here, one unit increase in each of the bacteria indicator present increased deaths by $2.67, \mathrm{I} .8 \mathrm{I}, \mathrm{I} .62$ and 1.09 respectively. However, some Local Government Areas reveal lower results. For example, result of Anambra West records 0 deaths on account of gastroenteritis infection an indication of a slow rise in death rate of 0.19 from feacal coliform infection. This is equally true for Nnewi South and
Oyi where the regression coefficients indicate very mild increases in deaths as a result of the infections.

Across the state, the equation shows a worrisome situation as all the bacteria indicators recorded high number of deaths per unit increase. The feacal coliform had the greatest impact of $2.8 \mathrm{I}$ given that all other variables are held constant. These findings are not different from those in studies by Fletcher et al (20I5) and Nzeakor and Okafor (200I) on the contaminants responsible for the spread of gastroenteritis among children. The regression equation model provides a check on the accuracy of the model application using the residuals (Hollman and Boyet, 1975). The result of the residual, which is the difference between the actual value of the dependent variable, the number of deaths $(y)$ and the expected value calculated from the regression equation is shown in Table 4. 
Table 4: The residual of the regression equation

\begin{tabular}{|c|c|c|c|c|}
\hline LGA & $y$ & Y'est & Y-Y'est & $\left({\text { Y-Y'est })^{2}}^{2}\right.$ \\
\hline Aguata & 20 & 21.2 & -1.2 & 1.44 \\
\hline Anambra East & 3 & 2.8 & 0.2 & 0.04 \\
\hline Anambra West & 0 & 0.48 & -0.48 & 0.23 \\
\hline Anaocha & I & 0.61 & 0.39 & 0.15 \\
\hline Awka North & 0 & 1.1 & -1.1 & 1.21 \\
\hline Awka North & 4 & 2.44 & 1.56 & 2.43 \\
\hline Ayamelum & 2 & I & I & I \\
\hline Dunukofia & 2 & 2.42 & -0.42 & 0.18 \\
\hline Ekwusigo & 2 & 1.92 & -0.08 & 0.01 \\
\hline Idemili North & I & 0.62 & 0.38 & 0.14 \\
\hline Idemili South & 22 & 20.64 & 1.36 & 1.85 \\
\hline Ihiala & 11 & 13.2 & -2.2 & 4.84 \\
\hline Njikoka & 13 & 11.69 & 1.31 & 1.72 \\
\hline Nnewi North & 4 & 2.86 & 1.14 & 1.29 \\
\hline Nnewi South & 0 & 0.71 & $-0.7 \mid$ & 0.5 \\
\hline Ogbaru & 5 & 4.82 & 0.18 & 0.03 \\
\hline Onitsha North & 4 & 2.28 & 1.72 & 2.96 \\
\hline Onitsha South & 10 & 13.2 & -3.2 & 10.24 \\
\hline Orumba North & 0 & 0.29 & -0.29 & 0.08 \\
\hline Orumba South & 8 & 6.48 & 1.52 & 2.31 \\
\hline \multirow[t]{3}{*}{ Oyi } & 0 & 0.17 & -0.17 & 0.29 \\
\hline & & & & $\Sigma\left(y-y^{\prime} \text { est }\right)^{2}$ \\
\hline & & & & 32.94 \\
\hline
\end{tabular}

Source: Authors Analysis

A number of important observations are seen in the residual analyses results in Table 4 as concern total number of deaths in the Local Government Areas. Firstly, the regression model did estimate the actual value of deaths in 10 Local Government Areas, as indicated by negatives signs. In Onitsha South, the value of -3.20 is very high, while the rest of the Local Government Areas have minimal values. The remarkable value in Onitsha South is attributed to the quality of domestic water sampled in that area. At 95\% confidence level, the Standard Error of Estimate (SEE)SEE value was 1.50 which is an indication that the prediction of the number of deaths resulting from gastroenteritis infection is minimal. The true ' $y$ ' lies within the limits $+/-I .50$ at $95 \%$ confidence level, reflecting the relative accuracy of the estimates of the number of deaths using regression model.

The gastroenteritis disease is a preventable disease if we ensure a clean environment and maintain good personal hygiene. The haphazard way and manner feacal disposal is done needs an urgent intervention in the area of instituting and ensuring an implementation action of proper waste collection and disposal while strengthening health institutions. It is an eyesore to encounter feacal waste dumped (usually in a nearby bush) in an anyhow-anywhere manner creating a breeding ground for flies, beetles and other microbial pathogens that usually cause infection to humans. At the onset of rains these pathogens either infiltrate the soil or are washed by 
flood into farmlands, streams, shallow wells, broken down water pipes and other domestic water sources.

Anambra State is currently collaborating with the UN and other relevant stakeholders in a 5-year strategic multisectoral program from 2017- 2022. To this effect a call was made for support of the framework for achieving SDG's come 2030, by the State government in the First Anambra-Development Partner's Summit held in Awka, on August 2017. The summit with the theme-"Strengthening Partnerships to Attain SDGs before 2030"- is a platform for key players in development planning to deepen their partnerships towards the implementation of Anambra State strategic plan (Anaso 2017). The aim is to proffer innovative, inclusive and effective strategies geared towards attaining the UN SDGs agenda in the State. A recommendation was made for the collaboration of the State Government, Federal Ministry of Budget and National Planning, OSSAPSDGs, UN System, the Organized Private Sector and CSOs towards the implementation of SDGs in Anambra State (Anaso, 2017).

\section{Conclusion}

Epidemiological studies really do not establish the cause and effect of public health problems, but they often provide strong evidence for the most likely cause. This study has shown that the near-epidemic incidents of gastroenteritis recorded in Anambra State, Southeast Nigeria between 2004 and 2008 had a spatial pattern and occurred in clusters with the highest of the 287 deaths occurring in Idemili North/South constituency. The study further showed that the consumption of contaminated water was responsible for the spread of the disease as evident from the relationship between water properties measured with respect to aerobic heterotrophic count (AC), total coliform (TC), feacal coliform (FC) and enterococci (EN) and fatalities associated with gastroenteritis in the study area.

It is observed that the huge number of deaths could have been averted by stepping up levels of environmental and personal hygiene as well as the rapid responsiveness by government, NGO's and all stakeholders to the provision of potable water and good health facilities. The resort to sourcing domestic water from springs, wells streams and water vendor is a direct result of the non-existence of pipe-borne water or dysfunctional pipe borne water facilities in areas within the affected constituencies. To avoid a repeat of such avoidable calamities, this study is suggesting preventive measures like good hand washing practices, food hygiene, proper waste collection and disposal in addition to the provision of basic infrastructure for improved health outcomes among the population.

\section{References}

Akande, T.A. (2017) Why Gastroenteritis Kills Children Faster. Evening Newsletter, Interviewed by Toluwani, Eniola, September 3.

Amieva, M. R. (2005) Important Gastrointestinal Pathogens in Children; A Pathogenesis Perspective. Pediatric Clinics of North America, Vol, 52 No 3 pp. 749-777.

Ayolabi, C.I. (2010) Isolation and Molecular Characterisation of some Viruses associated with Gastroenteritis among Children under 5 Years in Lagos State, Nigeria. Department of Microbiology, University of Agriculture, Abeokuta.

British Medical Association (2002) Illustrated Medical Dictionary. Dorling Kinderslay Publishers, New York p. 245-246.

Ciccarelli S, Stolfi I, Caramia G (2013) Management Strategies in the Treatment of Neonatal and Pediatric Gastroenteritis. Infection and Drug Resistance. 6: |33-6|

Ezechukwu, C. U. (2008) The Nigerian Child in the Midst of Plenty, II $^{\text {th }}$ Inaugural Lecture, Nnamdi Azikiwe University, Awka.

Fagbami, A.H., Johnson, O.A. \& David-West, T.S. (1985) Rotavirus Infection in Children Presenting with Acute Gastroenteritis in Ibadan, Nigeria. Transactions of the Royal Society of Tropical Medicine and Hygiene, 79,(I): II4-II5

Federal Ministry of Health, Abuja (2008) National Policy on Integrated Disease Surveillance and Response (IDSR) pp. I-34

Fletcher, S, McLaws, M. and Ellis, J. (20/3) Prevalence of Gastrointestinal Pathogens in Developed and Developing Countries: Systematic Review and Meta-Analysis. Journal of Public Health Research, 2013 Apr 28; 2(I): 42-53.

Fletcher S, Sibbritt, D, Stark, D, Harkness, J, Rawlinson, W, Andresen, D, Van Hal, S, Merif, J and Ellis, J. (2015) Descriptive epidemiology of infectious gastrointestinal illnesses in Sydney, Australia, 2007-2010. Western Pacific Surveillance and Response Journal, 20I5, 6(4):7-16.

Government of Anambra State, Nigeria, Ministry of Health, (2009). Infant Gastroenteritis Surveillance Data, Epidemiological Surveillance Unit, Awka.

Hollman, K. W. and Boyet, W. E. (1975) An Empirical Analysis of Water Pricing Determinants in Municipalities; Journal of American Water Works Association, Vol. 67, (3), 274-28I.

Jorge, S. (2014) Over 90 million Nigerians live on less than two dollars per day. Vanguard News, July 15

Liacouras, C. and Markowitz J. E. (1999) Eosinophilic Esophagitis: A subset of Eosinophilic Gastroenteritis, Current Gastroenterology Reports, Vol. I. Pp. 253-258. 
Mayer, J. R. (200I) Connections in Environmental Science: A case study Approach. McGraw-Hill, New York, pp. 286-290

Nzeako, B. \& Okafor, N. (200I) Bacterial Enteropathogens and Factors Associated with Seasonal Episodes of Gastroenteritis in Nsukka, Nigeria. British Journal of Biomedical Science 59: 76-79. 23.

O'Dell, D. S. (1973) Medical Effects of Pollutants in Keith Tearl (ed), Industrial Pollution Control: The Practical Implication, Business Books. Ltd., London, pp. 22-27.

Obienusi, E. A. (2006) Pollution Management in a Paper Industry: An example from Jebba Papermill, Jebba, Nigeria, Geo-Studies Vol. 3, Nos I \&2, pp. 22-33.

Paul, M.O, et al. (1982) Rotavirus Infection in Nigerian Infants and Young Children with

Gastroenteritis. American Journal of Tropical Medical Hygiene 3I(2), pp. 374-375
Rehan, S., Yehuda, K. And Balvant, R. . (2006) Estimating Risks of Contaminants Intrusion in Water Distributive Networks usuing Dempster Shaffer Theory of Evidence. Taylor and Francis, National Research Council, Canada

Rinquist, E.J. (1995) Political Control and Policy Impact in EPAs Office of Water Quality. American Journal of Political Science, 39 (2)

United Nations (2015) The World Population Prospects: 2015 Revision, Department of Economic and Social Affairs, New York

United Nations Public Informarion Bureau [UNPIB] (2015) Time For Global Action for People and Planet.

WHO (2015) World Health Rankings www.worldlifeexpentancy.com/nigeria-lifeexpectancy.

Wilmoth, J. (2015) Time For Global Action for People and Planet Press Release of the United Nations Public Information

Bureau. 